\title{
Preservation of microbial communities enriched on lignocellulose under thermophilic and high-solid conditions
}

\author{
Chaowei Yu ${ }^{1}$, Amitha P. Reddy ${ }^{1,2}$, Christopher W. Simmons ${ }^{2,3}$, Blake A. Simmons ${ }^{2,4}$, Steven W. Singer 2,5 \\ and Jean S. VanderGheynst ${ }^{1,2^{*}}$ (D)
}

\begin{abstract}
Background: Microbial communities enriched from diverse environments have shown considerable promise for the targeted discovery of microorganisms and enzymes for bioconversion of lignocellulose to liquid fuels. While preservation of microbial communities is important for commercialization and research, few studies have examined storage conditions ideal for preservation. The goal of this study was to evaluate the impact of preservation method on composition of microbial communities enriched on switchgrass before and after storage. The enrichments were completed in a high-solid and aerobic environment at $55^{\circ} \mathrm{C}$. Community composition was examined for each enrichment to determine when a stable community was achieved. Preservation methods included cryopreservation with the cryoprotective agents DMSO and glycerol, and cryopreservation without cryoprotective agents. Revived communities were examined for their ability to decompose switchgrass under high-solid and thermophilic conditions.

Results: High-throughput 165 rRNA gene sequencing of DNA extracted from enrichment samples showed that the majority of the shift in composition of the switchgrass-degrading community occurred during the initial three 2-week enrichments. Shifts in community structure upon storage occurred in all cryopreserved samples. Storage in liquid nitrogen in the absence of cryoprotectant resulted in variable preservation of dominant microorganisms in enriched samples. Cryopreservation with either DMSO or glycerol provided consistent and equivalent preservation of dominant organisms.

Conclusions: A stable switchgrass-degrading microbial community was achieved after three 2-week enrichments. Dominant microorganisms were preserved equally well with DMSO and glycerol. DMSO-preserved communities required more incubation time upon revival to achieve pre-storage activity levels during high-solid thermophilic cultivation on switchgrass. Despite shifts in the community with storage, the samples were active upon revival under thermophilic and high-solid conditions. The results suggest that the presence of microorganisms may be more important than their relative abundance in retaining an active microbial community.
\end{abstract}

Keywords: Biological lignocellulose deconstruction, Cryopreservation, Microbial community enrichment

\section{Background}

Development of economical and sustainable conversion technologies for production of lignocellulosic biofuels is needed to meet the one billion gallon renewable fuel requirement set in the 2013 Clean Air Act [1-5].

\footnotetext{
*Correspondence: jsvander@ucdavis.edu

2 Joint BioEnergy Institute, Emeryville, CA 94608, USA

Full list of author information is available at the end of the article
}

Lignocellulosic biomass feedstocks, such as agricultural residues and dedicated energy crops, are primarily composed of complex matrices of polysaccharides (cellulose and hemicellulose) and lignin which form plant cell walls [3]. These complex plant cell walls are recalcitrant to biological conversion, resulting in a high cost for pretreatment and enzymatic hydrolysis [3, 6-8]. The discovery of efficient and economically viable enzymes and microorganisms for use at the industrial scale would significantly 
lower the production cost of ethanol from lignocellulosic biomass [8-10].

The industrial processes for converting lignocellulosic biomass to liquid fuel typically require enzymes that function at extreme conditions, such as high temperature, high-solid loading, and low moisture [9-11]. Microbial communities found in nature, such as in compost and soil environments, are very efficient at deconstructing lignocellulosic plant biomass and are a potential source of such enzymes. However, compost and soil ecosystems are often too complex for direct identification of deconstructive microorganisms and enzymes. To address this, enrichment culture, where engineered culture conditions are used to promote growth of microorganisms with specific traits, has been applied [11-15]. In enrichment cultures to promote growth of lignocellulolytic microorganisms, biomass feedstocks are used as substrate and complex communities, such as those found in compost or soil are applied as inoculum $[11,16]$. Cultures are subjected to thermophilic and high-solid loading conditions to simulate environments relevant to industrial biofuel production. The enrichment process generates less complex lignocellulolytic microbial communities that can facilitate targeted discovery of potential enzymes and microorganisms for biomass deconstruction [11].

Preservation of enriched microbial communities is important for industrial applications and research [17, 18]. For long-term storage of individual microorganisms, cryopreservation and lyophilization are two major methods used; however, cryopreservation is generally preferred over lyophilization due to potential cell damage during the drying process [19]. Proper preservation methods should not change the morphology, physiology and genetics of the organism [18]. To minimize cellular damage during cryopreservation and thawing processes, microorganisms are typically preserved in the presence of cryoprotective agents, such as dimethyl sulfoxide (DMSO) and glycerol [20]. While there have been many studies examining storage of individual microorganisms, few studies have focused on preservation of microbial communities and evaluation of preservation methods using high-throughput DNA sequencing $[17,18,21]$.

The goal of this study was to evaluate the composition of microbial communities enriched on switchgrass before and after application of different preservation methods. The enrichments were completed in a high-solid and aerobic environment at $55{ }^{\circ} \mathrm{C}$. Community composition was examined for each enrichment to determine when a stable community was achieved. Preservation methods included cryopreservation with the cryoprotective agents DMSO and glycerol, and preservation without cryoprotective agents. Revived communities were examined for their ability to decompose switchgrass under high-solid and thermophilic conditions.

\section{Results}

Enrichment of the switchgrass-degrading community

Carbon dioxide evolution rate (CER) profiles for incubations $\mathrm{T} 1$ and $\mathrm{T} 6$ are shown in Fig. 1. In the initial enrichment period, respiration rate increased rapidly at the beginning of incubation, reached a peak activity at approximately 1.3 days with an average rate of $55 \mathrm{mg} \mathrm{CO} \mathrm{g}^{-1}$ dry matter day ${ }^{-1}$, and then dropped rapidly (Fig. 1a). A second peak in respiration occurred on day 3 and a third peak was observed on day 8; these two peaks were consistent with the watering and mixing schedule (every 3-4 days).

In successive enrichments, the first peak in activity tended to occur sooner during incubation. For T6 the first peak occurred at $9.6 \mathrm{~h}$ (Fig. 1b). A second peak was also observed for the T6 enrichment at around 3 days. In the respiration profile for $\mathrm{T} 6$, the $\mathrm{CO}_{2}$ evolution rate at the first peak was around $110\left(\mathrm{mg} \mathrm{CO}_{2} \mathrm{~g}^{-1}\right.$ dry matter

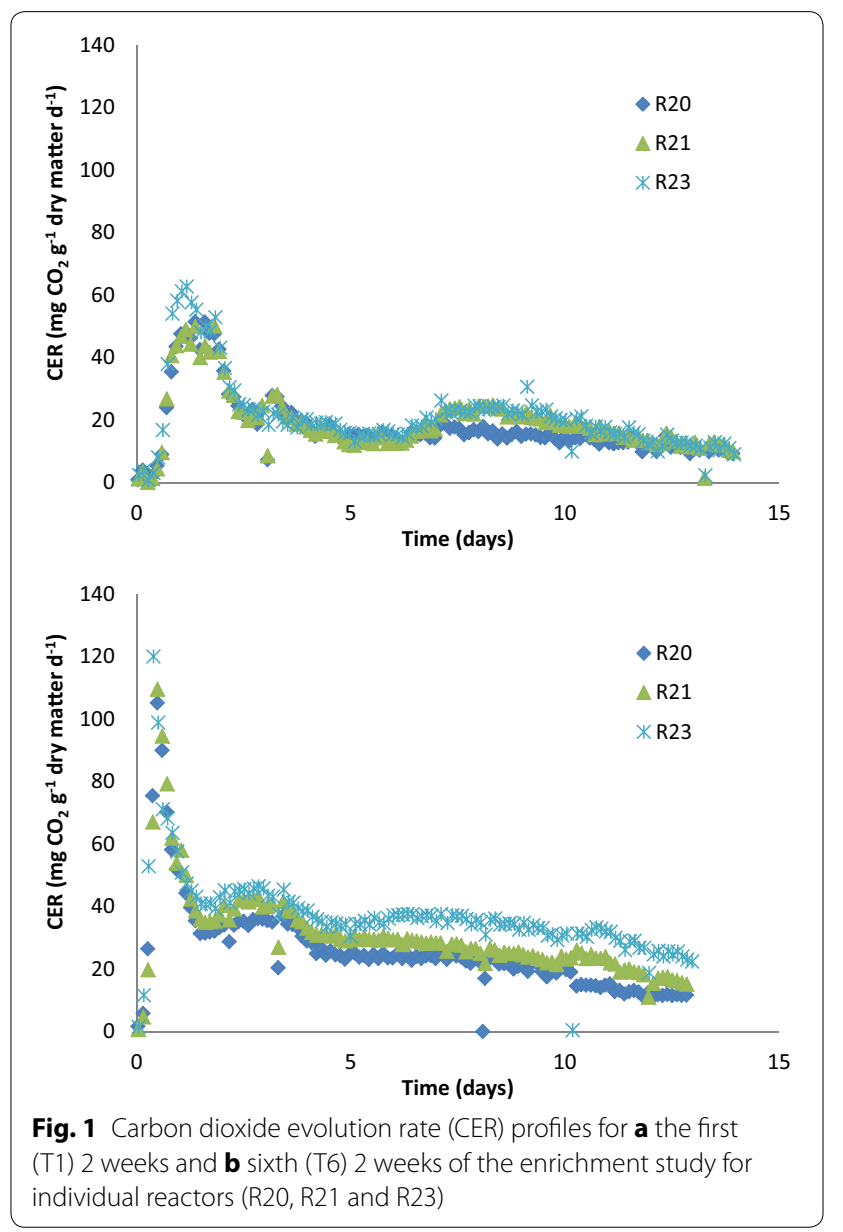


Table 1 Cumulative carbon dioxide evolution rate (CCER) for each enrichment

\begin{tabular}{llll}
\hline \multicolumn{4}{c}{ Mean cCER $\mathbf{( m g} \mathbf{C O}_{\mathbf{2}} \mathbf{~}^{\mathbf{- 1}}$ dry matter $)^{\mathbf{a}}$} \\
\cline { 2 - 4 } & 3-day & $\mathbf{5}$-day & $\mathbf{1 2 . 7 - \text { day }}$ \\
\hline T1 & $90(7) \mathrm{A}$ & $128(8) \mathrm{A}$ & $258(24) \mathrm{A}$ \\
$\mathrm{T} 2$ & $98(9) \mathrm{A}, \mathrm{B}$ & $147(11) \mathrm{A}, \mathrm{B}$ & $280(16) \mathrm{A}$ \\
$\mathrm{T} 3$ & $119(7) \mathrm{C}, \mathrm{D}$ & $176(10) \mathrm{C}$ & $312(25) \mathrm{A}, \mathrm{B}$ \\
$\mathrm{T} 4$ & $113(14) \mathrm{B}, \mathrm{C}$ & $160(26) \mathrm{C}$ & $293(67) \mathrm{A}, \mathrm{B}$ \\
$\mathrm{T}$ & $119(7) \mathrm{C}, \mathrm{D}$ & $168(11) \mathrm{C}, \mathrm{D}$ & $294(29) \mathrm{A}, \mathrm{B}$ \\
$\mathrm{T}$ & $136(10) \mathrm{D}$ & $204(21) \mathrm{D}$ & $400(71) \mathrm{B}$ \\
\hline
\end{tabular}

a Standard deviation in parenthesis $(n=3)$. Means followed by the same letter within incubation periods are not statistically different at $\alpha=0.05$ based on Tukey-Kramer HSD test, blocked by reactor

day $^{-1}$ ), which was 2 times greater than the initial peak for $\mathrm{T} 1$. The higher peak respiration indicates higher metabolic activity, suggesting that the community in T6 was better adapted for switchgrass decomposition than the community in $\mathrm{T} 1$.

The improved ability of the microbial community to decompose switchgrass with each enrichment was also assessed by measuring cumulative respiration (cCER). Different time periods were examined based on peaks observed in the respiration profiles (Fig. 1). During the first 3 days of incubation when the rate of microbial activity was the greatest, average cCER increased with each enrichment (Table 1); the 3-day cCER for T6 was significantly higher than for T1. The cumulative $\mathrm{CO}_{2}$ evolution rates (cCER) for each reactor at the end of each 5- and 12.7-day incubation period are also provided in Table 1 . The 12.7-day cCER for T6 was significantly higher than $\mathrm{T} 1(p<0.05)$, but the 12.7-day cCER values for T3, T4, $\mathrm{T} 5$, and $\mathrm{T} 6$ were not significantly different, suggesting that the community was likely stabilized between T3 and T6 enrichments.

The microbial community shifted in structure over the course of enrichment (Fig. 2). The T1 microbial communities for the three replicated reactors were similar; however, as enrichment progressed, each replicate tended to shift to a unique microbial community structure. Shifts in phylum abundance were also observed (Fig. 3; Table 2). The dominant phyla included Chloroflexi, Proteobacteria, Bacteroidetes and Actinobacteria. Chloroflexi was the most abundant ( $42 \%$ ) phylum in the compost inoculum (T0), dropped to $7-10.5 \%$ in the initial enrichment T1, and significantly increased to $15-19 \%$ in T6. Between T0 and T1, the relative abundance of Bacteroidetes increased from $5 \%$ up to $24 \%$, and significantly decreased to 13-18 \% by T6. Abundance levels of Proteobacteria increased from an initial 15 up to $35 \%$ after the first 2 weeks of enrichment and remained relatively constant.

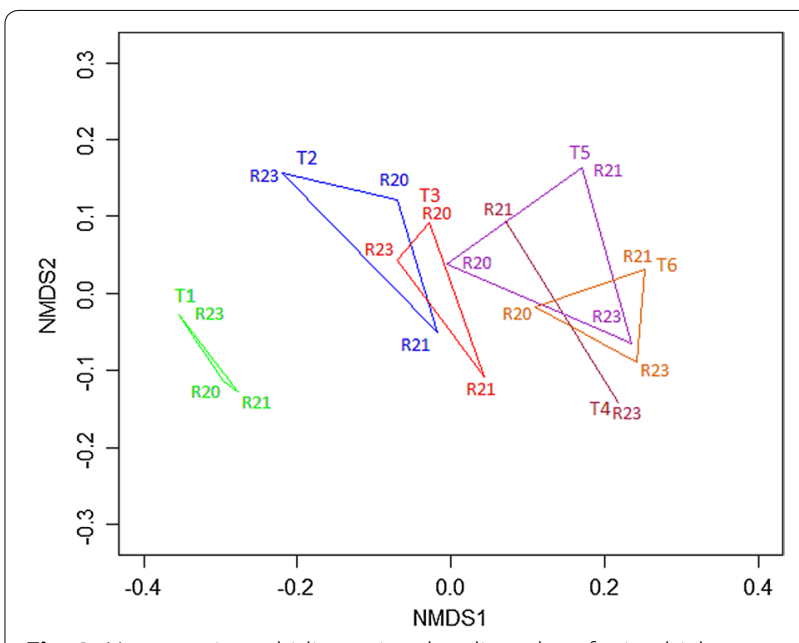

Fig. 2 Non-metric multidimensional scaling plot of microbial communities grouped by enrichment time points. Three replicates are shown for all time periods except $\mathrm{T} 4$ samples which had 2 replicates

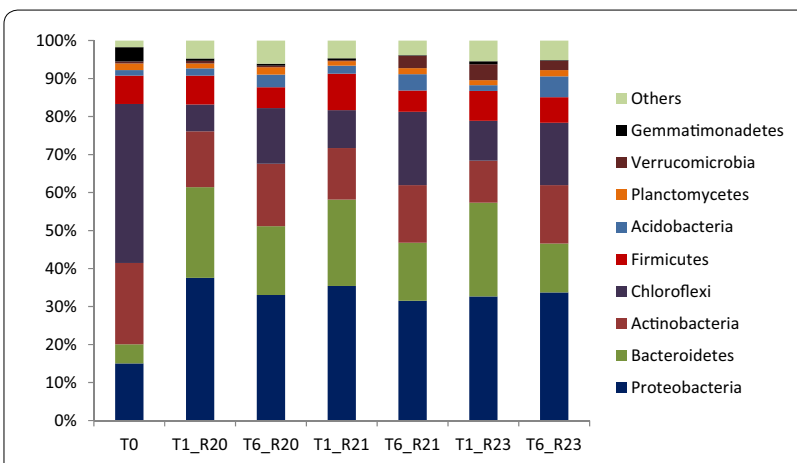

Fig. 3 Relative abundance of phyla in communities at enrichment time $T 0, T 1$, and $T 6$

The relative abundance of Actinobacteria decreased between $\mathrm{T} 0$ and $\mathrm{T} 1$ and remained relatively constant during the remaining enrichments. Similar trends were observed in all three reactors.

The microbial community diversity decreased between $\mathrm{T} 0$ and $\mathrm{T} 1$ and stayed relatively constant between $\mathrm{T} 1$ and T6 (Fig. 4). The richness of the communities decreased after 2 weeks of enrichment (T0 to T1), continued to decrease slowly between $\mathrm{T} 1$ and $\mathrm{T} 3$, and became stable after T3 (Table 3). The evenness of the communities in all reactors dropped after the first 2-week enrichment but gradually increased with later enrichments. The evenness in R20 became steady after T3 while both R21 and R23 continued to increase after T3. Bray-Curtis dissimilarity values for all three reactors were close to 1 when comparing the communities at time $\mathrm{T} 0$ and $\mathrm{T} 1$, indicating that the initial community structure (T0) and the community structures after the first 2 weeks of enrichment 
Table 2 Mean relative abundance (\%) of dominant phyla in communities T1 and T6

\begin{tabular}{|c|c|c|c|c|c|c|c|c|c|c|}
\hline & $\begin{array}{l}\text { Acidobac- } \\
\text { teria }\end{array}$ & $\begin{array}{l}\text { Actinobac- } \\
\text { teria }\end{array}$ & $\begin{array}{l}\text { Bacteroi- } \\
\text { detes }\end{array}$ & Chloroflexi & Firmicutes & $\begin{array}{l}\text { Planctomy- } \\
\text { cetes }\end{array}$ & $\begin{array}{l}\text { Proteobac- } \\
\text { teria }\end{array}$ & $\begin{array}{l}\text { Verrucomi- } \\
\text { crobia }\end{array}$ & $\begin{array}{l}\text { Gemmati- } \\
\text { monadetes }\end{array}$ & Other phyla \\
\hline T1 & $1.84 \mathrm{~A}$ & $13.11 \mathrm{~A}$ & $23.75 \mathrm{~A}$ & $9.18 \mathrm{~A}$ & $8.34 \mathrm{~A}$ & $1.27 \mathrm{~A}$ & $35.22 \mathrm{~A}$ & $1.73 \mathrm{~A}$ & $0.61 \mathrm{~A}$ & $4.96 \mathrm{~A}$ \\
\hline T6 & $4.39 \mathrm{~B}$ & $15.66 \mathrm{~A}$ & $15.41 \mathrm{~B}$ & $16.78 \mathrm{~B}$ & $5.94 \mathrm{~B}$ & $1.73 \mathrm{~B}$ & $32.76 \mathrm{~A}$ & $2.03 \mathrm{~A}$ & $0.29 \mathrm{~A}$ & $5.03 \mathrm{~A}$ \\
\hline
\end{tabular}

Means followed by the same letter within columns are not statistically different at $a=0.05$ based on Tukey-Kramer HSD test

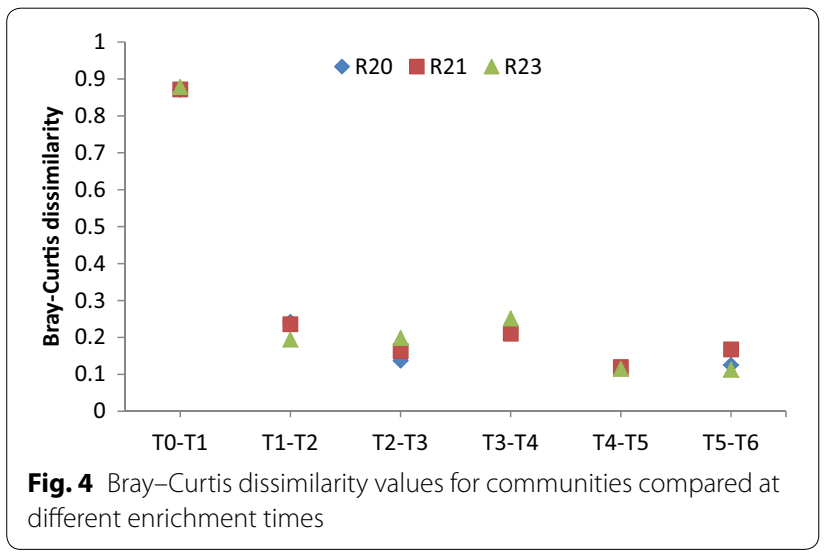

(T1) were very different (Fig. 4). However, as enrichment progressed from $\mathrm{T} 1$ to $\mathrm{T} 6$, Bray-Curtis dissimilarity values for all three reactors decreased and stayed relatively stable with the lowest values observed between $\mathrm{T} 4$ and T5. The analyses of richness, evenness and dissimilarity suggest that a relatively stable switchgrass-degrading community was achieved by enrichment T3 (Table 3).

SIMPER analysis revealed that Sphingobacteriales was the largest contributor to dissimilarity between T1 and T6 enrichment time points for all three reactors (Table 4); its relative abundance decreased with enrichment. Other organisms that contributed to dissimilarity in all reactors included Anaerolineae and Micromonosporaceae, which both increased with enrichment.

Despite all communities originating from the same inoculum source and identical culture conditions, there were differences in the evolution of the enriched communities (Additional file 1: Figure S1). Comparisons of dissimilarity between enriched microbial communities for each reactor at the final enrichment (T6) showed Roseiflexales to be the largest contributor to dissimilarity. Two different species were detected and levels varied between enrichment times and reactors. Very low levels were detected in R23. For R20, relative abundance averaged $6 \%$ for T2-T6, while for R21 relative abundance was low until enrichment T4 at which time levels increased to $7-8 \%$.

\section{Influence of storage methods on culture preservation}

The cumulative carbon dioxide evolution rates (cCER) for all treatments are shown in Table 5. The cCER levels of reactors measured on day 3 and day 6 show that both $-80{ }^{\circ} \mathrm{C}$ and DMSO-treated samples had significantly lower activities than control and glycerol-treated samples. The higher activities in glycerol-treated samples were likely due to the presence of glycerol in the re-inoculated feedstock and its potential utilization as a carbon source. The cCER levels at 12.7 days were between 311 and 388 ( $\mathrm{mg} \mathrm{CO}_{2} \mathrm{~g}^{-1}$ dry matter). At 12.7 days there were no significant differences between treatments.

The cCER of each treatment was also examined relative to the cCER of the inoculum (T6). The comparisons were calculated as ratios (Table 5). In general, the ratios of both control and glycerol-treated samples were greater than $-80{ }^{\circ} \mathrm{C}$ and DMSO-treated samples, indicating that both $-80{ }^{\circ} \mathrm{C}$ and DMSO may not have preserved the active microbial community responsible for switchgrass decomposition. However, for DMSO-treated samples, the ratio was relatively low on day 3 and 6 but increased toward the end of the incubation. It is possible that the DMSO-treated community required a longer time to acclimate to the growth environment compared to communities preserved in glycerol.

The NDMS plot indicates that there was a shift in the community structure of the stored microbial communities upon inoculation and incubation on switchgrass (Fig. 5). The largest shift occurred with $-80{ }^{\circ} \mathrm{C}$ storage in the absence of cryoprotectant. Unlike DMSO and glycerol-treated communities, which tended to cluster together on the NDMS plot, each of the reactor communities diverged during storage at $-80^{\circ} \mathrm{C}$. The results indicate $-80^{\circ} \mathrm{C}$ storage in the absence of cryoprotectant would provide inconsistent preservation of thermophilic communities enriched on switchgrass. For this reason, samples from this treatment were not considered for further comparisons.

The microbial community of the inoculum and control samples (T7) had equivalent values for diversity, richness and evenness (Table 6). In general, values for these diversity indices decreased with preservation. The richness of samples preserved with DMSO and glycerol was significantly smaller than inoculum (T6) and T7 samples. Bray-Curtis dissimilarity values for inoculum communities compared to control communities were small $(<0.34)$, indicating that the inoculum community structures and control community structures were similar (Table 6). 
Table 3 Mean Shannon diversity, richness, Pielou's evenness and Bray-Curtis dissimilarity values for microbial communities by enrichment times

\begin{tabular}{lllll}
\hline & Shannon diversity & Richness & Evenness & $\begin{array}{l}\text { Bray-Curtis dissimilarity } \\
\text { comparisons to T1 }\end{array}$ \\
\hline T0 & 4.20 & 790 & 0.63 & 0.87 \\
T1 & $3.18 \mathrm{~A}$ & $268 \mathrm{~A}$ & $0.57 \mathrm{~A}$ & 0 \\
T2 & $3.06 \mathrm{~A}$ & $192 \mathrm{~B}$ & $0.58 \mathrm{~A}, \mathrm{~B}$ & $0.22 \mathrm{~A}$ \\
T3 & $3.02 \mathrm{~A}$ & $160 \mathrm{C}$ & $0.59 \mathrm{~A}, \mathrm{~B}$ & $0.26 \mathrm{~A}, \mathrm{~B}$ \\
T4 & 3.07 & 154 & 0.61 & 0.33 \\
T5 & $3.07 \mathrm{~A}$ & $156 \mathrm{C}$ & $0.61 \mathrm{~B}$ & $0.32 \mathrm{~B}$ \\
T6 & $3.11 \mathrm{~A}$ & $155 \mathrm{C}$ & $0.62 \mathrm{~B}$ & $0.33 \mathrm{~B}$ \\
\hline
\end{tabular}

Means followed by the same letter within columns are not statistically different at $a=0.05$ based on Tukey-Kramer HSD test, blocked by reactor. Time point 4 was excluded from the statistical analysis due to insufficient DNA in one sample. T0 included only one sample

Table 4 OTUs that contribute $>4 \%$ to Bray-Curtis dissimilarity between T1 and T6 communities

\begin{tabular}{|c|c|c|c|c|}
\hline Reactor & Abundance in T1 sample (\%) & Abundance in T6 sample (\%) & $\%$ Contribution to dissimilarity & OTU classification $^{a}$ \\
\hline R20 & 23.59 & 17.96 & 9.91 & 9_Sphingobacteriales \\
\hline R20 & 2.62 & 7.80 & 9.11 & c_Anaerolineae \\
\hline R20 & 2.92 & 7.69 & 8.40 & g_Micromonosporaceae \\
\hline R20 & 6.39 & 2.88 & 6.17 & 9_Streptosporangiaceae \\
\hline R20 & 2.62 & 5.55 & 5.16 & g_Roseiflexales (OTU 10) \\
\hline R20 & 2.39 & 0 & 4.21 & g_Balneimonas \\
\hline R21 & 22.49 & 15.08 & 11.54 & 9_Sphingobacteriales \\
\hline R21 & 0.01 & 5.94 & 9.23 & g_Roseiflexales (OTU 18) \\
\hline R21 & 4.23 & 9.06 & 7.52 & c_Anaerolineae \\
\hline R21 & 2.60 & 6.93 & 6.74 & g_Micromonosporaceae \\
\hline R21 & 6.29 & 3.27 & 4.70 & 9_Sinobacteraceae \\
\hline R23 & 24.58 & 12.68 & 15.88 & 9_Sphingobacteriales \\
\hline R23 & 5.17 & 11.02 & 7.80 & c_Anaerolineae \\
\hline R23 & 0.67 & 6.27 & 7.47 & g_Micromonosporaceae \\
\hline R23 & 4.17 & 0.40 & 5.02 & g_Chthoniobacter \\
\hline R23 & 6.31 & 2.64 & 4.89 & 9_Streptosporangiaceae \\
\hline R23 & 1.21 & 4.41 & 4.27 & g_Candidatus Solibacter \\
\hline
\end{tabular}

${ }^{a}$ Letter codes indicate the highest resolved taxonomy from phylogenetic binning: $k$ kingdom, $p$ phylum, $c$ class, $o$ order, $f$ family, $g$ genus

Bray-Curtis dissimilarity values were greater for DMSOand glycerol-treated samples indicating both preservation methods altered the community structure present in the inoculum. The greatest differences were observed for the glycerol-treated community.

The relative abundances of several phyla were affected by storage treatments (Table 7). Actinobacteria and Firmicutes were both resilient to cryopreservation; the relative abundance of these phyla significantly increased with treatment. The relative abundances of Chloroflexi and Planctomycetes in DMSO and glycerol-treated samples were significantly lower than the control and inoculum samples. Acidobacteria, Bacteroidetes, Proteobacteria and Verrucomicrobia did not change with preservation.
Very small changes in relative abundance were observed between the inoculum and control communities. SIMPER analysis indicated that Sphingobacteriales was a large contributor to dissimilarity between T6 and T7 enrichment time points (Table 8). The abundance of Sphingobacteriales decreased slightly with additional enrichment between the inoculum (T6) and control (T7).

Micromonosporaceae, Anaerolineae and Roseiflexales contributed $>4 \%$ to dissimilarity between the inoculum and DMSO and glycerol treatments for all reactors. Micromonosporaceae was the top contributor to dissimilarity between T6 and DMSO and glycerol samples (Tables 9, 10); its abundance increased with storage. Anaerolineae and Roseiflexales decreased in all treatments. 
Table 5 Cumulative carbon dioxide evolution rate (CCER) of control (T7) and stored treatments measured after 3, 6 and 12.7 days of incubation

\begin{tabular}{|c|c|c|c|c|c|c|}
\hline & \multicolumn{3}{|c|}{ Mean cCER $\left(\mathrm{mg} \mathrm{CO}_{2} \mathrm{~g}^{-1}\right.$ dry matter) } & \multicolumn{3}{|c|}{ Mean ratio ${ }^{a}$} \\
\hline & 3-day & 6-day & 12.7-day & 3-day & 6-day & 12.7-day \\
\hline T7 & 125 (17) $A B$ & $250(66) \mathrm{A}$ & 369 (97) A & $0.91 \mathrm{~A}$ & $1.06 \mathrm{~A}$ & $0.96 \mathrm{~A}$ \\
\hline$-80^{\circ} \mathrm{C}$ & $97(31) B C$ & 156 (34) B & 311 (36) A & $0.70 \mathrm{~B}$ & $0.66 \mathrm{~B}$ & $0.83 \mathrm{~A}$ \\
\hline DMSO & $91(15) \mathrm{C}$ & $161(22) \mathrm{B}$ & 388 (31) A & $0.66 \mathrm{~B}$ & $0.69 \mathrm{~B}$ & $1.07 \mathrm{~A}$ \\
\hline Glycerol & $130(34) \mathrm{A}$ & 228 (58) A & $384(70) A$ & $0.94 \mathrm{~A}$ & $0.97 \mathrm{~A}$ & $1.02 \mathrm{~A}$ \\
\hline
\end{tabular}

a Ratio of (CCER post storage)/(CCER of T6)

${ }^{b}$ Standard deviation in parenthesis $(n=3)$. Means followed by the same letter within columns and incubation periods are not statistically different at $a=0.05$ based on Tukey-Kramer HSD test, blocked by reactor

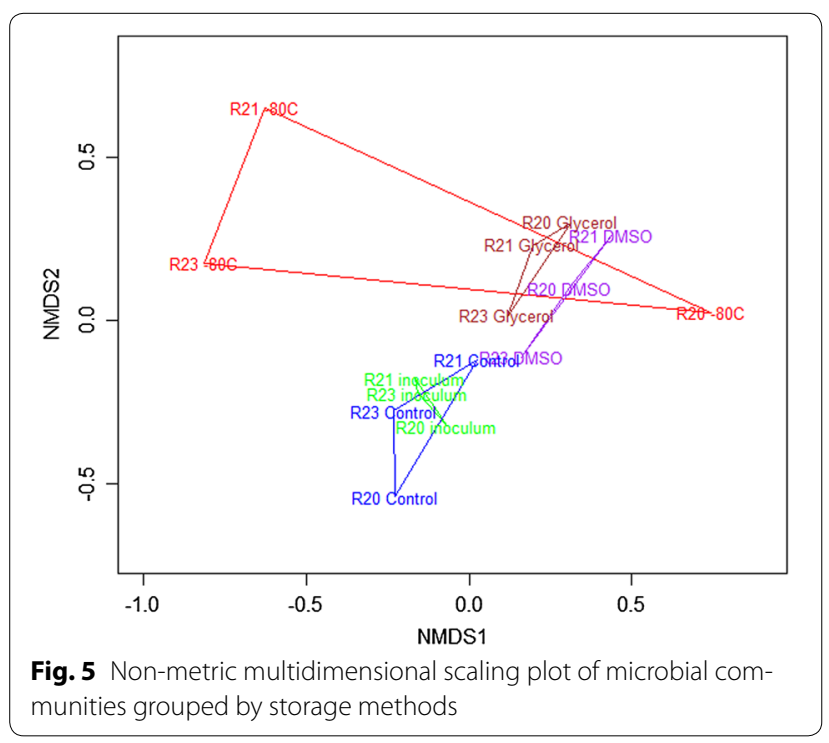

The abundance of Chelatococcus increased after microbial communities were stored in glycerol (data from R23 not shown) and DMSO (data from R21 and R23 not shown). The abundance of Thermobacillus in R20 and R21 also increased after microbial communities were stored in DMSO and glycerol.

Steroidobacteria was also a top contributor to dissimilarity between T6 and DMSO samples, and between T6 and glycerol samples in R20 and R21. The abundance of Steroidobacteria in R20 and R21 decreased after storage with DMSO and glycerol. These findings suggest that DMSO and glycerol storage conditions were not favorable for Anaerolineae, Roseiflexales and Steroidobacter, but did favor Micromonosporaceae, Chelatococcus, and Thermobacillus.

\section{Discussion}

Experiments were done to determine the number of enrichment passages necessary to achieve a stable

Table 6 Mean Shannon diversity, richness, Pielou's evenness and Bray-Curtis dissimilarity values for microbial communities from different treatments

\begin{tabular}{|c|c|c|c|c|}
\hline & Shannon diversity ${ }^{a}$ & Richness $^{a}$ & Evenness $^{a}$ & $\begin{array}{l}\text { Bray-Curtis dissimilarity } \\
\text { comparison to inoculum }^{a}\end{array}$ \\
\hline Inoculum & $3.11 \mathrm{~A}, \mathrm{~B}$ & $155 \mathrm{~A}$ & $0.62 A, B$ & 0 \\
\hline Control & $3.20 \mathrm{~A}$ & $160 \mathrm{~A}$ & $0.63 \mathrm{~A}$ & $0.21 \mathrm{~A}$ \\
\hline DMSO & $2.71 \mathrm{~B}$ & $131 \mathrm{~B}$ & $0.56 \mathrm{~B}$ & $0.39 \mathrm{~A}, \mathrm{~B}$ \\
\hline Glycerol & $2.83 \mathrm{~A}, \mathrm{~B}$ & $132 \mathrm{~B}$ & $0.58 \mathrm{~A}, \mathrm{~B}$ & $0.41 \mathrm{~B}$ \\
\hline
\end{tabular}

${ }^{a}$ Means followed by the same letter within columns are not statistically different at $\alpha=0.05$ based on Tukey-Kramer HSD test, blocked by reactor

Table 7 Mean relative abundance (\%) of phyla in communities

\begin{tabular}{|c|c|c|c|c|c|c|c|c|c|}
\hline & $\begin{array}{l}\text { Acidobac- } \\
\text { teria }\end{array}$ & $\begin{array}{l}\text { Actinobac- } \\
\text { teria }\end{array}$ & $\begin{array}{l}\text { Bacteroi- } \\
\text { detes }\end{array}$ & Chloroflexi & Firmicutes & $\begin{array}{l}\text { Planctomy- } \\
\text { cetes }\end{array}$ & $\begin{array}{l}\text { Proteobac- } \\
\text { teria }\end{array}$ & $\begin{array}{l}\text { Verrucomi- } \\
\text { crobia }\end{array}$ & $\begin{array}{l}\text { Other } \\
\text { phyla }\end{array}$ \\
\hline Inoculum & $4.39 \mathrm{~A}$ & $15.66 \mathrm{~A}$ & $15.41 \mathrm{~A}$ & $16.78 \mathrm{~A}$ & $5.94 \mathrm{~A}$ & $1.73 \mathrm{~A}$ & $32.76 \mathrm{~A}$ & $2.03 \mathrm{~A}$ & $5.31 \mathrm{~A}$ \\
\hline Control & $4.81 \mathrm{~A}$ & $17.89 \mathrm{~A}$ & $9.27 \mathrm{~A}$ & $15.3 \mathrm{~A}$ & $6.60 \mathrm{~A}, \mathrm{~B}$ & $1.60 A, B$ & $38.82 \mathrm{~A}$ & $1.48 \mathrm{~A}$ & $4.20 \mathrm{~A}, \mathrm{~B}$ \\
\hline DMSO & $6.11 \mathrm{~A}$ & 30.23 B & $17.20 \mathrm{~A}$ & 4.75 B & $11.35 \mathrm{~B}, \mathrm{C}$ & $0.24 C$ & $27.02 \mathrm{~A}$ & $0.99 \mathrm{~A}$ & $2.11 \mathrm{~A}, \mathrm{~B}$ \\
\hline Glycerol & $4.56 \mathrm{~A}$ & $24.92 B$ & $17.55 \mathrm{~A}$ & $3.46 \mathrm{~B}$ & $11.75 \mathrm{C}$ & $0.63 B, C$ & 34.69 A & $1.13 \mathrm{~A}$ & $1.30 \mathrm{~B}$ \\
\hline
\end{tabular}

Means followed by the same letter within columns are not statistically different at $a=0.05$ based on Tukey-Kramer HSD test, blocked by reactor ( $n=3$ ) 
Table 8 OTUs that contribute $>4 \%$ to Bray-Curtis dissimilarity between inoculum communities (T6) and control (T7) communities

\begin{tabular}{|c|c|c|c|c|}
\hline Reactor & Abundance in T6 sample (\%) & Abundance in T7 sample (\%) & $\%$ Contribution to dissimilarity & OTU classification ${ }^{a}$ \\
\hline R20 & 17.96 & 5.45 & 18.19 & g_sphingobacteriales \\
\hline R20 & 5.55 & 0.84 & 6.85 & g_Roseiflexales (OTU 10) \\
\hline $\mathrm{R} 20$ & 0.06 & 4.76 & 6.83 & g__Alkalilimnicola \\
\hline R20 & 5.57 & 1.08 & 6.54 & k__Bacteria \\
\hline R20 & 0.21 & 4.11 & 5.66 & g_Rhizobiales \\
\hline R20 & 1.52 & 5.13 & 5.25 & g_Pseudoxanthomonas \\
\hline R21 & 6.93 & 15.39 & 22.55 & g_Micromonosporaceae \\
\hline $\mathrm{R} 21$ & 15.08 & 9.41 & 15.13 & g__sphingobacteriales \\
\hline $\mathrm{R} 21$ & 3.93 & 7.51 & 9.55 & g_chelatococcus \\
\hline R21 & 5.94 & 3.32 & 6.97 & g_Roseiflexales (OTU 18) \\
\hline $\mathrm{R} 21$ & 3.21 & 1.00 & 5.89 & g__Streptosporangiaceae \\
\hline R23 & 11.02 & 13.05 & 10.98 & c_Anaerolineae \\
\hline R23 & 6.27 & 4.49 & 9.64 & g__Micromonosporaceae \\
\hline R23 & 4.83 & 3.21 & 8.75 & g__Chelatococcus \\
\hline R23 & 0.42 & 1.53 & 5.99 & g_ Roseiflexales (OTU 18) \\
\hline R23 & 1.44 & 0.38 & 5.71 & g_ Rhizobiales \\
\hline R23 & 4.72 & 5.54 & 4.46 & k_Bacteria \\
\hline R23 & 0.77 & 1.59 & 4.46 & g_schlegelella \\
\hline
\end{tabular}

a Letter codes indicate the highest resolved taxonomy from phylogenetic binning: $k$ kingdom, $p$ phylum, $c$ class, $o$ order, $f$ family, $g$ genus

Table 9 OTUs that contribute $>4 \%$ to Bray-Curtis dissimilarity between inoculum communities (T6) and DMSO communities

\begin{tabular}{|c|c|c|c|c|}
\hline Reactor & Abundance in T6 sample (\%) & Abundance in DMSO sample (\%) & $\%$ Contribution to dissimilarity & OTU classification ${ }^{a}$ \\
\hline R20 & 7.69 & 27.96 & 25.35 & g_Micromonosporaceae \\
\hline R20 & 18.47 & 7.04 & 14.29 & g__Steroidobacter \\
\hline R20 & 2.69 & 8.62 & 7.41 & g_Chelatococcus \\
\hline R20 & 5.55 & 0.77 & 5.98 & g_Roseiflexales (OTU 10) \\
\hline R20 & 5.57 & 0.80 & 5.96 & k_Bacteria \\
\hline R20 & 0.38 & 5.01 & 5.79 & g_Thermobacillus \\
\hline R20 & 7.80 & 4.31 & 4.36 & c_Anaerolineae \\
\hline R21 & 6.93 & 27.67 & 20.96 & g_Micromonosporaceae \\
\hline R21 & 17.14 & 2.06 & 15.23 & g_Steroidobacter \\
\hline R21 & 1.02 & 9.20 & 8.26 & g_thermobacillus \\
\hline R21 & 9.06 & 1.57 & 7.56 & c_Anaerolineae \\
\hline R21 & 15.08 & 22.51 & 7.51 & g_sphingobacteriales \\
\hline R21 & 5.94 & 0.04 & 5.96 & g_Roseiflexales (OTU 18) \\
\hline R23 & 6.27 & 19.91 & 23.80 & g_Micromonosporaceae \\
\hline R23 & 11.02 & 4.48 & 11.42 & c_Anaerolineae \\
\hline R23 & 0.15 & 5.50 & 9.33 & g_Brevibacillus \\
\hline R23 & 4.72 & 1.72 & 5.24 & k_Bacteria \\
\hline R23 & 4.17 & 1.64 & 4.43 & g_Roseiflexales (OTU 10) \\
\hline
\end{tabular}

${ }^{a}$ Letter codes indicate the highest resolved taxonomy from phylogenetic binning: $k$ kingdom, $p$ phylum, $c$ class, $o$ order, $f$ family, $g$ genus

microbial community capable of degrading switchgrass under thermophilic and high-solid conditions. In general, enrichment beyond T3 did not significantly affect microbial activity or microbial community structure.
Sphingobacteria was the largest contributor to dissimilarity between T1 and T6 enrichment time points for all three reactors (Table 4); levels were approximately $23 \%$ at T1 and declined to approximately $16 \%$ at T6. Certain 
Table 10 OTUs that contribute $>4 \%$ to Bray-Curtis dissimilarity between inoculum communities (T6) and glycerol communities

\begin{tabular}{|c|c|c|c|c|}
\hline Reactor & Abundance in T6 sample (\%) & Abundance in glycerol sample (\%) & $\%$ Contribution to dissimilarity & OTU classification $^{a}$ \\
\hline R20 & 18.47 & 2.43 & 17.06 & g__Steroidobacter \\
\hline R20 & 7.69 & 23.71 & 17.03 & g__Micromonosporaceae \\
\hline $\mathrm{R} 20$ & 2.69 & 11.05 & 8.89 & g_chelatococcus \\
\hline R20 & 7.80 & 1.12 & 7.10 & c_Anaerolineae \\
\hline R20 & 0.38 & 6.79 & 6.82 & g_thermobacillus \\
\hline R20 & 5.57 & 0.35 & 5.55 & k_Bacteria \\
\hline R20 & 5.55 & 0.35 & 5.53 & g_Roseiflexales (OTU 10) \\
\hline R21 & 6.93 & 22.47 & 18.20 & g_ Micromonosporaceae \\
\hline R21 & 17.14 & 4.59 & 14.69 & g__Steroidobacter \\
\hline R21 & 1.02 & 9.76 & 10.23 & g_thermobacillus \\
\hline R21 & 5.94 & 0.03 & 6.92 & g_Roseiflexales (OTU 18) \\
\hline R21 & 3.93 & 8.88 & 5.79 & g_chelatococcus \\
\hline $\mathrm{R} 21$ & 9.06 & 4.45 & 5.39 & c__Anaerolineae \\
\hline R23 & 6.27 & 16.21 & 14.83 & g_ Micromonosporaceae \\
\hline R23 & 11.02 & 1.94 & 13.54 & c_Anaerolineae \\
\hline R23 & 12.68 & 18.47 & 8.64 & g_sphingobacteriales \\
\hline R23 & 4.72 & 0.97 & 5.59 & k_Bacteria \\
\hline R23 & 1.58 & 5.29 & 5.52 & g_Phyllobacteriaceae \\
\hline R23 & 4.17 & 0.79 & 5.04 & g__Roseiflexales (OTU 10) \\
\hline R23 & 1.44 & 4.65 & 4.79 & g__Rhizobiales \\
\hline
\end{tabular}

${ }^{a}$ Letter codes indicate the highest resolved taxonomy from phylogenetic binning: $k$ kingdom, $p$ phylum, $c$ class, $o$ order, $f$ family, $g$ genus

species within Sphingobacteria have been observed in an aerobic soil containing decomposing rice callus under mesophilic conditions [22, 23]. In these studies, the experiments were conducted for 56 days, and Sphingobacteria became more dominant with decomposition. Sphingobacteria have also been found to positively interact with algal growth in municipal wastewater at room temperature [24]. A gene (xynA19) cloned from Sphingobacteria sp. TN19 was found in the gut of Batocera horsfieldi larvae, and it has been reported to be a xylanase-encoding gene [25]. An earlier study of wheat straw enriched with chicken manure showed that an isolated Sphingobacteria was able to metabolize lignin in a thermophilic environment [26]. The relative abundance of Sphingobacteria has been reported to increase after the microbial community from sediments was enriched on wheat straw under alkaline ( $\mathrm{pH} 9$ ), anaerobic, and mesophilic conditions [27]. Furthermore, Sphingobacteria have been shown to have the ability to deconstruct hemicellulose in wheat straw enriched with soil at $25^{\circ} \mathrm{C}$ in aerobic conditions [28, 29]. Clearly, Sphingobacteria can survive in both aerobic and anaerobic conditions and in mesophilic and thermophilic environments. In the present study, however, the decrease in relative abundance between $\mathrm{T} 1$ and $\mathrm{T} 6$ may have been due to adaptation and increase in abundance of other microorganisms in the community.
Anaerolineae was the second largest contributor to dissimilarity between $\mathrm{T} 1$ and $\mathrm{T} 6$ for reactors $\mathrm{R} 20$ and R23 and it was the third largest contributor to dissimilarity for reactor R21. Anaerolineae have previously been found in anaerobic wastewater treatment processes, rice paddy soil, and a deep terrestrial hot aquifer [30, 31]. Anaerolinea thermophila was discovered in a thermophilic $\left(55^{\circ} \mathrm{C}\right)$ anaerobic sludge treating organic wastewater and it was suggested to play a role in degradation of organic compounds such as carbohydrates and amino acids [3133]. In the present study, the abundance of Anaerolineae increased with enrichment time. It is possible that there were anaerobic pockets in the samples and air could not diffuse into the pockets, resulting in the survival of Anaerolineae.

Micromonosporaceae was the third largest contributor to dissimilarity between $\mathrm{T} 1$ and $\mathrm{T} 6$ for reactors R20 and R23 (Table 4) and it was the fourth largest contributor to dissimilarity for reactor R21. Two species, $M$. aurantiaca and $M$. carbonacea, have been identified in rice straw compost [34, 35], and M. carbonacea was able to break down cellulose, hemicelluloses, and lignin in rice straw composted with chicken manure [34]. Several studies showed that cellulose can be degraded by certain species within Micromonospora in thermophilic environments $[13,36,37]$. A prior study also showed that $M$. aurantiaca 
was stable over a wide temperature range $\left(55-70{ }^{\circ} \mathrm{C}\right)$ [35]. In addition, Micromonospora spp. was reported in previous studies to effectively degrade lignocellulosic wastes in aerobic conditions $[13,38,39]$. Similarly, in the present study, the enrichments were carried out in thermophilic and aerobic conditions, and the abundance of Micromonosporaceae increased as enrichment time increased.

Balneimonas (in the Bradyrhizobiaceae family) was one of the notable contributors to dissimilarity (4.21\%) between T1 and T6 in reactor R20 (Table 4). The abundance of Balneimonas decreased to $0 \%$ as enrichment time increased from T1 to T6. Similar results were observed in R21 and R23. Balneimonas was previously found in the roots of Pennisetum glaucum in the Kavango of Namimia, in Arabidopsis soil, and in soil crusts in the Kalahari of southern Africa [40-42]. Prior studies were under very dry conditions, opposite to the humid conditions in the present study suggesting that a dry environment may be more favorable for Balneimonas. Also, Balneimonas was observed in mesophilic conditions in these prior studies; our findings indicate that a thermophilic environment may not be favorable for the growth of Balneimonas.

In the order Actinomycetales, the family Streptosporangiaceae was a noticeable contributor to dissimilarity between $\mathrm{T} 1$ and $\mathrm{T} 6$ in all three reactors. Prior studies have shown the growth of Streptosporangiaceae in soil, rice compost, sugar cane bagasse compost, coffee hulls composts, and swine manure compost [43-45]. In the present study, the abundance of Streptosporangiaceae decreased with enrichment. It is possible that other microorganisms became more dominant with enrichment reducing the relative abundance of Streptosporangiaceae.

In cryopreservation, the biophysical changes caused by the transition of water to ice during the cooling period are the main causes of cell damage [46]. The rate of cooling controls the concentration of solution surrounding the cell and, therefore, influences the rate of water transport out of cells during cooling [19]. In cryopreservation, cells are introduced to cryogenic temperatures which results in ice crystals in the suspension medium and within cells. Thus, the osmotic shock can induce disruption of organelles and loss of membrane integrity, and cause cell injuries and death [18, 46-49]. In an ideal cryopreservation process, water transports out of cells rapidly to maintain equal salt concentration between extracellular and intracellular media, ice formation occurs externally to the cells, and internal cell damage is prevented [19, 46, 50, 51]. If the cooling rate is too fast, there is not sufficient time for water to transport from the more dilute intracellular solution to the concentrated extracellular medium, resulting in damage to the cell membrane $[19,46]$.
Cryoprotectants are typically classified into two categories: penetrating and non-penetrating. Penetrating cryoprotectants are more ideal because they protect the cell by lowering the freezing point of water promoting hydrogen bond formation and vitrification of solvents, and preventing ice crystal formation inside the cells [18, $46,57]$. Both glycerol and DMSO have cell-penetrating ability and are commonly used in cryopreservation of microorganisms [18]. DMSO can penetrate both the cell wall and cytoplasmic membrane within 15 and $30 \mathrm{~min}$ while it takes glycerol more than 30 min [19, 20]. Glycerol and DMSO can prevent osmotic shock by decreasing the freezing point of water and biological fluid to a minimum of -46 and $-73{ }^{\circ} \mathrm{C}$, respectively $[20,51,58,59]$.

While several prior studies have evaluated the effects of storage conditions, such as temperature and storage time, on changes in microbial community structure [5254], little work has been done to evaluate the effects of cryoprotective agents on community structure $[55,56]$. Ideally, the composition of microbial communities after storage should be the same as their initial states.

The relative abundances of Acidobacteria, Bacteroidetes, Proteobacteria and Verrucomicrobio were not affected by the storage methods suggesting that they can be preserved in either DMSO or glycerol at $-80{ }^{\circ} \mathrm{C}$. The relative abundances of Chloroflexi and Planctomycetes stored in DMSO and glycerol-treated samples were lower than the control and inoculum samples. So while DMSO and glycerol are typical cryoprotective agents used to reduce ice formation and thus prevent cell death during the freezing process [60], it is possible they were not effective for all organisms in T6 samples resulting in damage to organisms in phyla such as Chloroflexi and Planctomycetes during freezing. The relative abundance of Firmicutes was higher after storage with glycerol. Similar results were observed for samples from a cow rumen stored in glycerol at $-80^{\circ} \mathrm{C}[56]$. In the present study, the relative abundance of Actinobacteria increased after storage with glycerol at $-80^{\circ} \mathrm{C}$. A similar result was observed for Actinomycete strains stored in glycerol at $-80{ }^{\circ} \mathrm{C}$ for 3 months [55]. The relative abundances of Firmicutes and Actinobacteria were also higher after being stored with DMSO.

Storage conditions were not favorable for Anaerolineae, Roseiflexales and Steroidobacter, but did favor Micromonosporaceae, Chelatococcus, and Thermobacillus. A prior study observed that the relative abundance of Anaerolineae collected from either drained (60\% water holding capacity) or flooded paddy soil increased up to $3 \%$ after storing at either 4 or $-20^{\circ} \mathrm{C}$ for 30 days [61]. It is unclear whether the decrease in abundance of Anaerolineae in our experiments was caused by use of cryoprotectants or by the low-temperature storage condition in our study. 
Wang and co-workers also observed the abundances of Micromonosporaceae were unchanged before and after storage [61] which is in contrast to our findings. In our study, the increase in relative abundance of Micromonosporaceae could have been caused by the decrease in abundance of other microorganisms that did not tolerate preservation treatments. It is unclear if the actual abundance of Micromonosporaceae stayed the same before and after storage. One early study mixed dried rice straw with chicken, pig, and cattle feces under thermophilic conditions to create a compost community that was then used to inoculate Whatman filter paper [62]. This enrichment yielded a stable microbial community that included Thermobacillus, which remained stable for at least 1 year when stored at $-80{ }^{\circ} \mathrm{C}$ in a medium $[0.1 \%$ yeast extract, $0.5 \%$ peptone, $0.5 \% \mathrm{CaCO} 3,0.5 \% \mathrm{NaCl}$, and $\mathrm{H}_{2} \mathrm{O}(\mathrm{pH}$ 8.0)] with $20 \%(\mathrm{v} / \mathrm{v})$ glycerol $[62,63]$. In our study, the abundance of Thermobacillus increased after storage, suggesting that in addition to temperature and cryoprotectants, storing the community on the enrichment feedstock may be an important feature for long-term storage.

For Roseiflexales, Steroidobacter, and Chelatococcus, published storage methods include adding a cryoprotectant before storage. A study stored Roseiflexus at $-80{ }^{\circ} \mathrm{C}$ without any cryoprotectant [64]. Another study stored Steroidobacter in glycerol $(10 \%, \mathrm{v} / \mathrm{v})$ at $-80{ }^{\circ} \mathrm{C}$ for longterm storage [65]. One study isolated Chelatococcus from a sludge sample and stored the microorganism with $15 \%$ (v/v) glycerol at $-70{ }^{\circ} \mathrm{C}$ [66]. To the best of our knowledge, no study has evaluated the impact of storage conditions on the viability of these three organisms.

\section{Conclusions}

High-throughput 16S rRNA gene sequencing greatly assisted in elucidating the impact of enrichment and preservation methods on switchgrass-degrading microbial communities. The measurements made on enriched samples indicated that little change in microbial activity and microbial community structure occurred beyond three 2-week enrichments. Proper preservation methods should not significantly alter the composition of microbial communities after preservation. Preservation of samples in the absence of cryoprotectant resulted in variable changes in community composition. Samples preserved with DMSO and glycerol did experience a consistent shift in community composition though dominant microorganisms were retained in the active community. Despite shifts in the community with storage, the samples were active upon revival under thermophilic and high-solid conditions. The results suggest that the presence of microorganisms may be more important than their relative abundance in retaining an active microbial community.

\section{Methods}

\section{High-solid enrichments}

Finished green waste compost was obtained from a commercial facility that composts agricultural residues including tree and vine prunings (Northern Recycling, Zamora, CA). Compost was solar dried and stored at $4{ }^{\circ} \mathrm{C}$ until applied as inocula. Switchgrass (Panicum virgatum L.) was obtained from the Joint BioEnergy Institute (Emeryville, CA) and it was pretreated as described previously [67]. In summary, to remove water-soluble carbohydrates in switchgrass, dried switchgrass was extracted with water for 2 days followed by ethanol for 1.5 days in a soxhlet extractor. Extracted switchgrass was lyophilized at $-50{ }^{\circ} \mathrm{C}$ for at least $24 \mathrm{~h}$ until the residual solvent evaporated. Samples were stored in zipper lock bags at $4{ }^{\circ} \mathrm{C}$ until used in experiments. The compositions of the treated switchgrass have been reported previously [67].

High-solid incubations were conducted as described previously $[11,13]$. Bioreactors with a $0.2 \mathrm{~L}$ working volume were loaded with 5-11 g dry weight of switchgrass and inocula mixture. Prior to incubation, switchgrass was wetted with minimal media [12] to a moisture content of 400 wt $\%$ dry basis [g water (g dry solid) ${ }^{-1}$ ] and equilibrated at $4{ }^{\circ} \mathrm{C}$ overnight. For the initial enrichment in each experiment, wetted switchgrass was inoculated with 10 wt $\%$ [g dry compost (g dry solid $)^{-1}$ ] compost. The experiment was conducted with three replicates (R20, R21, and R23). Every 2 weeks, fresh feedstock was inoculated with $10 \mathrm{wt} \%$ [g dry enriched sample ( $\mathrm{g}$ total dry weight $)^{-1}$ ] of the enriched community and transferred to a new bioreactor. The enrichment experiment ran for 12 weeks, resulting in a total of six sampling points (T1, T2, T3, T4, T5, and T6).

House compressed air was humidified by bubbling it through distilled water and metered to each bioreactor with polycarbonate rotameters $\left(5-50 \mathrm{~mL}\right.$ air $\mathrm{min}^{-1}$, Dwyer Instruments, Inc., Michigan City, IN). Air was supplied to each bioreactor at $15 \mathrm{~mL} \mathrm{~min}{ }^{-1}$. Incubator temperature was maintained at $35{ }^{\circ} \mathrm{C}$ for 1 day, ramped to $55^{\circ} \mathrm{C}$ by increasing the temperature by $5{ }^{\circ} \mathrm{C}$ every $6 \mathrm{~h}$, and held at $55^{\circ} \mathrm{C}$ for the remainder of the enrichments. To maintain the moisture content, water was added to each bioreactor every 3-4 days and the contents were mixed.

Water was removed from the effluent of each reactor by passing through molecular sieves (3A, beads, 8-12 mesh particle size, Sigma-Aldrich, St. Louis, MO) and then passing through a small amount of indicating Drierite (W. A. Hammond Drierite Co., Ltd., Xenia, OH). Dry effluent from reactors was plumbed to a 16-position switching valve (VICI Valco Instruments, Houston, TX.), which switched positions every $20 \mathrm{~min}$ as controlled by a personal computer running LabVIEW software (Version 
2011 SP1, National Instruments Corp., Austin, TX). The effluent from the valve was sent to an infrared carbon dioxide $\left(\mathrm{CO}_{2}\right)$ sensor (Vaisala, Woburn, MA) and flow was measured with a thermal mass flow meter (Aalborg, Orangeburg, NY). Carbon dioxide and flow data were recorded by LabVIEW.

\section{Processing and storage of enriched communities}

The biomass in each reactor from the final enrichment (T6) was split into 4 subsamples for evaluating the effect of storage methods on the activity of inoculum. One of the subsamples was used immediately following the T6 enrichment to inoculate fresh feedstock at $10 \mathrm{wt} \%$ [g dry enriched sample ( $g$ total dry weight $)^{-1}$. Inoculated feedstock was transferred to a new bioreactor (control) for incubation for 2 weeks at $55^{\circ} \mathrm{C}$.

The remaining subsamples were subjected to the three following preservation methods: (1) $4 \mathrm{~g}$ wet weight mixed with $6 \mathrm{~g}$ of $7 \%$ DMSO by weight [in distilled-deionized water $\left.\left(\mathrm{DDH}_{2} \mathrm{O}\right)\right]$ and stored at $-80{ }^{\circ} \mathrm{C}$, (2) $4 \mathrm{~g}$ wet weight mixed with $6 \mathrm{~g}$ of $15 \%$ glycerol by weight (in $\mathrm{DDH}_{2} \mathrm{O}$ ) and stored at $-80{ }^{\circ} \mathrm{C}$, and (3) $4 \mathrm{~g}$ wet weight and stored at $-80^{\circ} \mathrm{C}$ without cryoprotectant. The final concentrations of DMSO and glycerol in preserved samples were 5 and $10 \%$, respectively. After 3 weeks of storage, fresh feedstock was inoculated with $10 \mathrm{wt} \%$ [g dry stored sample ( $\mathrm{g}$ dry solid $)^{-1}$ ] of the stored community. Inoculated feedstocks were transferred to bioreactors for incubation for 2 weeks at $55^{\circ} \mathrm{C}$.

\section{DNA extraction and 16S rRNA gene sequencing}

At the end of each enrichment, $9 \mathrm{~g}$ wet weightenriched feedstock was collected from each reactor, frozen in liquid nitrogen, homogenized with an oscillating ball mill (MM400, Retsch Inc., Newtown, PA), and extracted using a CTAB protocol [16]. Isolated DNA was purified to remove residual inhibitors using a DNeasy Blood and Tissue Kit (Qiagen, Venlo, the Netherlands). Three replicates were analyzed for all time periods except for T4 which had only 2 replicates, due to insufficient DNA.

Sequencing of a hypervariable region of the broadly conserved 16S rRNA gene was performed on purified DNA by the United States Department of Energy Joint Genome Institute using the Illumina Miseq platform, as previously described $[14,68]$. In summary, a fragment of the 16S rRNA gene was amplified from DNA extracts using PCR. The forward primer was the $515 \mathrm{f}$ primer with a $5^{\prime}$ Illumina adapter amended via pad and linker sequences. The reverse primer was the $806 \mathrm{r}$ primer with Illumina adapter compliment, barcode, pad and linker sequences amended to the $5^{\prime}$ end [68].

\section{Data analysis}

Respiration data from high-solid incubations were used to calculate $\mathrm{CO}_{2}$ evolution rates (CER) and cumulative respiration (cCER) from $\mathrm{CO}_{2}$ concentration and volumetric flow rate measurements of reactor effluents, as described previously [69]. CER values were normalized by the dry weight of material in the reactor. CCER values were obtained by integrating CER over time.

Sequences obtained through high-throughput sequencing of isolated DNA were quality trimmed, filtered, assembled and assigned to OTUs using methods described previously [68]. 16S rRNA gene read counts were used to conduct ecological and ordination analyses. Singletons were removed to reduce variability. Operational taxonomic unit (OTU) richness, evenness, and Shannon diversity values were computed in $\mathrm{R}$ (version 3.0.2, R Foundation for Statistical Computing, Vienna, Austria) using the Vegan package (https://vpn.lib.ucdavis. edu/,DanaInfo=CRAN.R-project.org+package=vegan).

Non-metric multidimensional scaling (NMDS) of Bray-Curtis dissimilarity values between communities was performed with Vegan's metaMDS function using 1000 random starts. Similarity percentage (SIMPER) analysis was conducted as described previously [70] to determine which OTUs contribute most to Bray-Curtis dissimilarity between certain communities.

Significant differences between treatments were identified using analysis of variance (ANOVA) and least significant difference with a significance level $\alpha=0.05$. Data were analyzed using SAS software (Version 9.4, SAS Institute Inc., Cary, NC).

\section{Additional file}

Additional file 1. Relative abundance of organisms in enriched communities in R20, R21, and R23 by enrichment time.

\section{Abbreviations}

CER: carbon dioxide evolution rate; CCER: carbon dioxide cumulative respiration; SIMPER: similarity percentages.

\section{Authors' contributions}

APR and JSV conceived the study and designed the experiments. APR and CY conducted enrichment cultures and storage experiments and APR, CY and JSV drafted sections of the manuscript describing community enrichment and storage. CY and CWS analyzed sequencing data. CY and JSV drafted sections of the manuscript describing sequencing results and SWS, CWS and BAS revised said sections. JSV, BAS and SWS provided resources for experiments. All authors read and approved the final manuscript.

\section{Author details}

${ }^{1}$ Department of Biological and Agricultural Engineering, University of California, One Shields Ave, Davis, CA 95616, USA. ${ }^{2}$ Joint BioEnergy Institute, Emeryville, CA 94608, USA. ${ }^{3}$ Department of Food Science and Technology, University of California, Davis, CA 95616, USA. ${ }^{4}$ Biological and Materials Science Center, Sandia National Laboratories, Livermore, CA 94551, USA. ${ }^{5}$ Earth Sciences Division, Lawrence Berkeley National Laboratory, Berkeley, CA 94720, USA. 


\section{Acknowledgements}

We thank Garren Lewis and Toni Leong for assistance with bioreactors. This work was supported by the UC Laboratory Fees Research Program \#12-LR237496, National Institute of Food and Agriculture project CA-D-BAE-2228-RR and the Joint BioEnergy Institute, supported by the US Department of Energy, Office of Science, Office of Biological and Environmental Research, through contract DE-AC02-05CH1 1231 between Lawrence Berkeley National Laboratory and the US Department of Energy. Sequencing was conducted by the Joint Genome Institute which is supported by the Office of Science of the U.S. Department of Energy under Contract No. DE-AC02-05CH11231.

\section{Competing interests}

The author(s) declare that they have no competing interests.

Received: 27 September 2015 Accepted: 17 November 2015 Published online: 02 December 2015

\section{References}

1. EPA. Regulation of fuels and fuel additives: 2013 renewable fuel standards; final rule. 2013;78:49794-830.

2. Parker N, Tittmann P, Hart Q, Nelson R, Skog K, Schmidt A, et al. Development of a biorefinery optimized biofuel supply curve for the Western United States. Biomass Bioenerg. 2010;34(11):1597-607. doi:10.1016/j. biombioe.2010.06.007.

3. Simmons BA, Loque D, Blanch HW. Next-generation biomass feedstocks for biofuel production. Genome Biol. 2008;9(242):1-6. doi:10.1186/ gb-2008-9-12-242

4. Somerville C, Youngs H, Taylor C, Davis SC, Long SP. Feedstocks for lignocellulosic biofuels. Science. 2010;329(5993):790-2. doi:10.1126/ science.1189268.

5. Borrion AL, McManus MC, Hammond GP. Environmental life cycle assessment of lignocellulosic conversion to ethanol: a review. Renew Sustain Energy Rev. 2012;16(7):4638-50. doi:10.1016/j.rser.2012.04.016.

6. Chandra RP, Bura R, Mabee WE, Berlin A, Pan X, Saddler JN. Substrate pretreatment: the key to effective enzymatic hydrolysis of lignocellulosics? In: Olsson L, editor. Biofuels. Advances in biochemical engineeringbiotechnology. 2007. p. 67-93.

7. Yang B,Wyman CE. Pretreatment: the key to unlocking low-cost cellulosic ethanol. Biofuels Bioprod Biorefining Biofpr. 2008;2(1):26-40. doi:10.1002/bbb.49.

8. Merino ST, Cherry J. Progress and challenges in enzyme development for biomass utilization. In: Olsson L, editor. Biofuels. Advances in biochemical engineering-biotechnology. 2007. p. 95-120.

9. Banerjee G, Scott-Craig JS, Walton JD. Improving enzymes for biomass conversion: a basic research perspective. BioEnerg Res. 2010;3(1):82-92. doi:10.1007/s12155-009-9067-5.

10. Klein-Marcuschamer D, Oleskowicz-Popiel P, Simmons BA, Blanch HW. The challenge of enzyme cost in the production of lignocellulosic biofuels. Biotechnol Bioeng. 2012;109(4):1083-7. doi:10.1002/bit.24370.

11. Reddy AP, Allgaier M, Singer SW, Hazen TC, Simmons BA, Hugenholtz P, et al. Bioenergy feedstock-specific enrichment of microbial populations during high-solids thermophilic deconstruction. Biotechnol Bioeng. 2011;108(9):2088-98. doi:10.1002/bit.23176.

12. DeAngelis KM, Gladden JM, Allgaier M, D'Haeseleer P, Fortney JL, Reddy A, et al. Strategies for enhancing the effectiveness of metagenomic-based enzyme discovery in lignocellulolytic microbial communities. BioEnerg Res. 2010;3(2):146-58. doi:10.1007/s12155-010-9089-z.

13. Reddy AP, Simmons CW, D'Haeseleer P, Khudyakov J, Burd H, Hadi M, et al. Discovery of microorganisms and enzymes involved in high-solids decomposition of rice straw using metagenomic analyses. PLoS ONE. 2013;8(10):12. doi:10.1371/journal.pone.0077985.

14. Simmons CW, Reddy AP, Simmons BA, Singer SW, VanderGheynst JS. Effect of inoculum source on the enrichment of microbial communities on two lignocellulosic bioenergy crops under thermophilic and highsolids conditions. J Appl Microbiol. 2014;. doi:10.1111/jam.12609.

15. Jimenez DJ, Dini-Andreote F, van Elsas JD. Metataxonomic profiling and prediction of functional behaviour of wheat straw degrading microbial consortia. Biotechnol Biofuels. 2014;7. doi:10.1186/1754-6834-7-92.
16. Allgaier M, Reddy A, Park JI, Ivanova N, D'Haeseleer P, Lowry S et al. Targeted discovery of glycoside hydrolases from a switchgrass-adapted compost community. PLoS One. 2010;5(1). doi:10.1371/journal. pone.0008812.

17. Kerckhof FM, Courtens ENP, Geirnaert A, Hoefman S, Ho A, Vilchez-Vargas $R$ et al. Optimized cryopreservation of mixed microbial communities for conserved functionality and diversity. PLoS One. 2014;9(6). doi:10.1371/ journal.pone.0099517.

18. Prakash O, Nimonkar Y, Shouche YS. Practice and prospects of microbial preservation. FEMS Microbiol Lett. 2013;339(1):1-9. doi:10.1111/1574-6968.12034.

19. Heylen K, Hoefman S, Vekeman B, Peiren J, De Vos P. Safeguarding bacterial resources promotes biotechnological innovation. Appl Microbiol Biotechnol. 2012;94(3):565-74. doi:10.1007/s00253-011-3797-y.

20. Hubalek Z. Protectants used in the cryopreservation of microorganisms. Cryobiology. 2003;46(3):205-29. doi:10.1016/s0011-2240(03)00046-4.

21. Tatangelo V, Franzetti A, Gandolfi I, Bestetti G, Ambrosini R. Effect of preservation method on the assessment of bacterial community structure in soil and water samples. FEMS Microbiol Lett. 2014;356(1):32-8. doi:10.1111/1574-6968.12475.

22. Lee CG, Watanabe T, Sato Y, Murase J, Asakawa S, Kimura M. Bacterial populations assimilating carbon from C-13-labeled plant residue in soil: analysis by a DNA-SIP approach. Soil Biol Biochem. 2011;43(4):814-22. doi:10.1016/j.soilbio.2010.12.016.

23. Li Y, Lee CG, Watanabe T, Murase J, Asakawa S, Kimura M. Identification of microbial communities that assimilate substrate from root cap cells in an aerobic soil using a DNA-SIP approach. Soil Biol Biochem. 2011;43(9):1928-35. doi:10.1016/j.soilbio.2011.05.016.

24. Lee J, Lee J, Lee TK, Woo SG, Baek GS, Park J. In-depth characterization of wastewater bacterial community in response to algal growth using pyrosequencing. J Microbiol Biotechnol. 2013;23(10):1472-7. doi:10.4014/ jmb.1303.03022.

25. Zhou JP, Huang HQ, Meng K, Shi PJ, Wang YR, Luo HY, et al. Molecular and biochemical characterization of a novel xylanase from the symbiotic Sphingobacterium sp TN19. Appl Microbiol Biotechnol. 2009;85(2):32333. doi:10.1007/s00253-009-2081-x.

26. Taylor CR, Hardiman EM, Ahmad M, Sainsbury PD, Norris PR, Bugg TDH. Isolation of bacterial strains able to metabolize lignin from screening of environmental samples. J Appl Microbiol. 2012;113(3):521-30 doi:10.1111/j.1365-2672.2012.05352.x.

27. Porsch K, Wirth B, Toth EM, Schattenberg F, Nikolausz M. Characterization of wheat straw-degrading anaerobic alkali-tolerant mixed cultures from soda lake sediments by molecular and cultivation techniques. Microbial Biotechnol. 2015:8(5):801-14. doi:10.1111/1751-7915.12272.

28. Jimenez DJ, Chaves-Moreno D, van Elsas JD. Unveiling the metabolic potential of two soil-derived microbial consortia selected on wheat straw. Sci Rep. 2015;5. doi:10.1038/srep13845.

29. Jimenez DJ, Korenblum E, van Elsas JD. Novel multispecies microbial consortia involved in lignocellulose and 5-hydroxymethylfurfural bioconversion. Appl Microbiol Biotechnol. 2014;98(6):2789-803. doi:10.1007/ s00253-013-5253-7.

30. Yamada T, Sekiguchi Y. Cultivation of uncultured chloroflexi subphyla: significance and ecophysiology of formerly uncultured chloroflexi 'subphylum i' with natural and biotechnological relevance. Microbes Environ. 2009;24(3):205-16. doi:10.1264/jsme2.ME09151S.

31. Narihiro T, Kamagata Y. Cultivating yet-to-be cultivated microbes: the challenge continues. Microbes Environ. 2013;28(2):163-5. doi:10.1264/ jsme2.ME2802rh.

32. Sekiguchi $Y$, Takahashi H, Kamagata $Y$, Ohashi A, Harada H. In situ detection, isolation, and physiological properties of a thin filamentous microorganism abundant in methanogenic granular sludges: a novel isolate affiliated with a clone cluster, the green non-sulfur bacteria, subdivision I. Appl Environ Microbiol. 2001;67(12):5740-9. doi:10.1128/ aem.67.12.5740-5749.2001.

33. Sekiguchi Y, Yamada T, Hanada S, Ohashi A, Harada H, Kamagata Y. Anaerolinea thermophila gen. nov., sp nov and Caldilinea aerophila gen. nov., sp nov., novel filamentous thermophiles that represent a previously uncultured lineage of the domain Bacteria at the subphylum level. Int J Sys Evol Microbiol. 2003;53:1843-51. doi:10.1099/ ijs.0.02699-0. 
34. Kausar H, Sariah M, Saud HM, Alam M, Ismail M. Isolation and screening of potential actinobacteria for rapid composting of rice straw. Biodegradation. 2011;22(2):367-75. doi:10.1007/s10532-010-9407-3.

35. Yeh YF, Chang SCY, Kuo HW, Tong CG, Yu SM, Ho THD. A metagenomic approach for the identification and cloning of an endoglucanase from rice straw compost. Gene. 2013;519(2):360-6. doi:10.1016/j. gene.2012.07.076

36. de Menezes AB, Lockhart RJ, Cox MJ, Allison HE, McCarthy AJ. Cellulose degradation by micromonosporas recovered from freshwater lakes and classification of these actinomycetes by DNA gyrase B gene sequencing. Appl Environ Microbiol. 2008;74(22):7080-4. doi:10.1128/aem.01092-08.

37. Gallagher J, Winters A, Barron N, McHale L, McHale AP. Production of cellulase and beta-glucosidase activity during growth of the actinomycete Micromonospora chalcae on cellulose-containing media. Biotechnol Lett. 1996;18(5):537-40.

38. Thawai C, Tanasupawat S, Itoh T, Suwanborirux K, Suzuki K, Kudo T. Micromonospora eburnea sp nov., isolated from a Thai peat swamp forest. Int J Sys Evol Microbiol. 2005;55:417-22. doi:10.1099/ijs.0.63217-0.

39. Wenzel M, Schonig I, Berchtold M, Kampfer P, Konig H. Aerobic and facultatively anaerobic cellulolytic bacteria from the gut of the termite Zootermopsis angusticollis. J Appl Microbiol. 2002;92(1):32-40. doi:10.1046/j.1365-2672.2002.01502.x.

40. Elliott DR, Thomas AD, Hoon SR, Sen R. Niche partitioning of bacterial communities in biological crusts and soils under grasses, shrubs and trees in the Kalahari. Biodivers Conserv. 2014;23(7):1709-33. doi:10.1007/ s10531-014-0684-8.

41. Gronemeyer JL, Burbano CS, Hurek T, Reinhold-Hurek B. Isolation and characterization of root-associated bacteria from agricultural crops in the Kavango region of Namibia. Plant Soil. 2012;356(1-2):67-82. doi:10.1007/ s11104-011-0798-7.

42. Zolla G, Badri DV, Bakker MG, Manter DK, Viyanco JM. Soil microbiomes vary in their ability to confer drought tolerance to Arabidopsis. Appl Soil Ecol. 2013:68:1-9. doi:10.1016/j.apsoil.2013.03.007.

43. de Gannes V, Eudoxie G, Hickey WJ. Prokaryotic successions and diversity in composts as revealed by 454-pyrosequencing. Bioresour Technol. 2013;133:573-80. doi:10.1016/j.biortech.2013.01.138.

44. Hayakawa M, Yamamura H, Nakagawa Y, Kawa Y, Hayashi Y, Misonou T, et al. Taxonomic diversity of actinomycetes isolated from swine manure compost. Actinomycetologica. 2010;24:58-62.

45. Koeck DE, Pechtl A, Zverlov W, Schwarz WH. Genomics of cellulolytic bacteria. Curr Opin Biotechnol. 2014;29:171-83. doi:10.1016/j. copbio.2014.07.002.

46. Fuller BJ. Cryoprotectants: the essential antifreezes to protect life in the frozen state. Cryoletters. 2004;25(6):375-88

47. Lovelock JE. The protective action of neutral solutes against haemolysis by freezing and thawing. Biochem J. 1954;56(2):265-70.

48. Mazur P. Principles of cryobiology. In: Fuller BJ, Lane N, Benson EE, editors. Life in the Frozen State. Boca Raton, FL: CRC; 2004.

49. Wowk B. How cryoprotectants work. In: Cryonics, vol 28. Alcor Life Extension Foundation; 2007, pp 3-7.

50. Mazur P. Cryobiology-freezing of biological systems. Science. 1970;168(3934):939. doi:10.1126/science.168.3934.939.

51. Meryman HT. Freezing injury and its prevention in living cells. Annual review of biophysics and bioengineering. 1974;3:341-63. doi:10.1146/ annurev.bb.03.060174.002013.

52. Lauber CL, Zhou N, Gordon Jl, Knight R, Fierer N. Effect of storage conditions on the assessment of bacterial community structure in soil and human-associated samples. FEMS Microbiol Lett. 2010;307(1):80-6. doi:10.1111/j.1574-6968.2010.01965.x.

53. Roesch LFW, Casella G, Simell O, Krischer J, Wasserfall CH, Schatz D, et al. Influence of fecal sample storage on bacterial community diversity. Open Microbiol J. 2009;3:40-6. doi:10.2174/1874285800903010040.

54. Rubin BER, Gibbons SM, Kennedy S, Hampton-Marcell J, Owens S, Gilbert JA. Investigating the impact of storage conditions on microbial community composition in soil samples. PLoS One. 2013;8(7). doi:10.1371/ journal.pone.0070460.

55. Filippova SN, Surgucheva NA, Kuznetsov VD, El'-Registan GI, Gal'chenko VF. Optimization of protective media for actinomycetes storage in liquid nitrogen. Microbiology. 2007;76(4):506-9. doi:10.1134/ s0026261707040194.
56. Fliegerova K, Tapio I, Bonin A, Mrazek J, Callegari ML, Bani P, et al. Effect of DNA extraction and sample preservation method on rumen bacterial population. Anaerobe. 2014;29:80-4. doi:10.1016/j.anaerobe.2013.09.015.

57. Chian RC. Cryobiology: an overview. Fertility cryopreservation. Cambridge, Montreal: Cambridge University Press; 2010.

58. Harrison AP. Causes of death of bacteria in frozen suspensions. Antonie Van Leeu Wenhoek J Microbiol Serol. 1956;22(4):407-18. doi:10.1007/ bf02538353.

59. Lovelock JE. The mechanism of the protective action of glycerol against haemolysis by freezing and thawing. Biochim Et Biophys Acta. 1953;11(1):28-36. doi:10.1016/0006-3002(53)90005-5.

60. Pegg DE. Principles of cryopreservation. In: Wolkers WF, Oldenhof H, editors. Cryopreservation and freeze-drying protocols. Methods in molecular biology, 3rd edn. 2015. p. 3-19.

61. Wang J, Chapman SJ, Yao HY. The effect of storage on microbial activity and bacterial community structure of drained and flooded paddy soil. J Soils Sediment. 2015;15(4):880-9. doi:10.1007/s11368-014-1053-7.

62. Haruta S, Cui Z, Huang Z, Li M, Ishii M, Igarashi Y. Construction of a stable microbial community with high cellulose-degradation ability. Appl Microbiol Biotechnol. 2002;59(4-5):529-34. doi:10.1007/s00253-002-1026-4

63. Wongwilaiwalin S, Rattanachomsri U, Laothanachareon T, Eurwilaichitr L, Igarashi Y, Champreda V. Analysis of a thermophilic lignocellulose degrading microbial consortium and multi-species lignocellulolytic enzyme system. Enzyme Microb Technol. 2010;47(6):283-90. doi:10.1016/j. enzmictec.2010.07.013.

64. Collins AM, Kirmaier C, Holten D, Blankenship RE. Kinetics and energetics of electron transfer in reaction centers of the photosynthetic bacterium Roseiflexus castenholzii. Biochim Et Biophys Acta Bioenerg. 2011;1807(3):262-9. doi:10.1016/j.bbabio.2010.11.011.

65. Fahrbach $M$, Kuever J, Remesch M, Huber BE, Kampfer P, Dott W, et al. Steroidobacter denitrificans gen. nov., sp nov., a steroidal hormone-degrading gammaproteobacterium. Int J Sys Evol Microbiol. 2008;58:2215-23. doi:10.1099/ijs.0.65342-0.

66. Jin L, Ko SR, Lee HG, Kim BH, Kim HS, Ahn CY, et al. Chelatococcus caeni sp nov., isolated from a biofilm reactor sludge sample. Int J Sys Evol Microbiol. 2015;65:885-9. doi:10.1099/ijs.0.000032.

67. Li CL, Knierim B, Manisseri C, Arora R, Scheller HV, Auer M, et al. Comparison of dilute acid and ionic liquid pretreatment of switchgrass: biomass recalcitrance, delignification and enzymatic saccharification. Bioresour Technol. 2010;101(13):4900-6. doi:10.1016/j.biortech.2009.10.066.

68. Simmons CW, Claypool JT, Marshall MN, Jabusch LK, Reddy AP, Simmons BA, et al. Characterization of bacterial communities in solarized soil amended with lignocellulosic organic matter. Appl Soil Ecol. 2014;73:97104. doi:10.1016/j.apsoil.2013.08.014

69. Reddy AP, Jenkins BM, VanderGheynst JS. The critical moisture range for rapic microbial decomposition of rice straw during storage. Trans Asabe. 2009;52(2):673-6.

70. Clarke KR. Nonparametric multivariate analyses of chances in community structure. Aust J Ecol. 1993;18(1):117-43. doi:10.1111/j.1442-9993.1993. tb00438.x.

\section{Submit your next manuscript to BioMed Central and we will help you at every step:}

- We accept pre-submission inquiries

- Our selector tool helps you to find the most relevant journal

- We provide round the clock customer support

- Convenient online submission

- Thorough peer review

- Inclusion in PubMed and all major indexing services

- Maximum visibility for your research

Submit your manuscript at www.biomedcentral.com/submit

C Biomed Central 